\title{
MET Codon 963 Splice Mutation
}

National Cancer Institute

\section{Source}

National Cancer Institute. MET Codon 963 Splice Mutation. NCI Thesaurus. Code

C147123.

A change in the nucleotide sequence of MET gene that alters splicing at codon 963. 